\title{
BUSINESS EXCELLENCE, LEADERSHIP AND LEAN: A SYSTEMATIC LITERATURE REVIEW
}

\author{
Fok-Yew Oon* \\ Universiti Tun Hussein Onn
}

Abdul Hamid Nor Aziati

Universiti Tun Hussein Onn

Abu Seman Esmadi Abu

Universiti Malaysia Sabah

\begin{abstract}
The objective of this study is to examine the prevailing literature on Business Excellence (BE), leadership and Lean. Leadership is enabling criteria of Business Excellence Models (BEMs) and Lean is one of the keys improvement initiative which can be adopted and the path forward in achieving BE. The analysis involved studying 506 research articles published between 2009 and Aug 2020 in well-known academic databases. This systematic literature review intends to organize, synthesize and structure the shared fount of knowledge concerning to BE, leadership and Lean. The classification and analysis of these articles are according to the following axes: years of publication, types of journals and research context. Each trend of the three axes is granted in the analysis. The main research fields are suggested to guide future research agenda of BEMs. This study focused on recent 11 years articles and ignored those studies from journals that are focusing on an area other than quality and management, dissertations and books. The results of the study would also benefit academicians, researchers, and professionals to focus on the pertinence, growth and research developments in the Lean management field and BE system. This study is possibly one such comprehensive systematic literature reviews focusing on a vital agenda of leadership and Lean management in BE. All the texts, tables and figures presented in this paper were original work carried out by authors.
\end{abstract}

Keywords: Business Excellence; Business Excellence Models; Leadership; Lean; Literature Review.

Received: 8 May 2020

Accepted: 30 December 2020

https://doi.org/10.33736/ijbs.3178.2021

\section{INTRODUCTION}

This systematic literary review purposes to organize, synthesize and structure the fount of knowledge concerning to Business Excellence (BE), leadership and Lean. The review is focused mostly on empirical studies and theoretical developments in the practice of BE.

\footnotetext{
* Corresponding author: Faculty of Technology Management \& Business (FPTP), Universiti Tun Hussein Onn Malaysia; Email: oonfokyew@gmail.com
} 
The term "Business Excellence" which began to be used in mid-1980s as the first Business Excellence Models (BEMs) were developed. The advancements in quality and competitiveness in Japan has forced the West in turn to this move and came about as a result of the quality movement (BPIR, 2019). Indeed, the BEMs emerged from Total Quality Management (TQM) models or quality award. TQM had started in the mid-1980s as the new panacea and philosophy for businesses particularly in the manufacturing industry. Since all kinds of business improvement initiatives were being named TQM, the term "Business Excellence" ongoing to replace the terms "Quality" and "TQM" over the time as partly to avoid confusion as to the meaning of TQM.

Today, BEMs are viewed as a key mechanism for improving the performance of organizations by many countries on top of national competitiveness. The BEMs are developed to guide and assist companies to improve their business performance and achieve world-class levels of performance. Besides, BEMs are basis for award programmes use by national bodies. This objective is serves to recognize and identify role model among organizations. Kanji (2002) emphasized that the most prominent BEMs are Malcolm Baldrige National Quality Award (MBNQA), European Foundation for Quality Management Excellence Model (EFQM EM), Deming Prize, Kanji's Business Excellence Model (KBEM) and Balanced Scorecard (BSC).

According to Mohammad, Mann, Grigg and Wagner (2011), majority of the preceding research on BEMs primarily focus on the validation and design of BEMs, for quality/BE awards, for organizational assessment, for organization best practices and benchmarking. Limited studies were conducted to investigate the utilization of BEMS as overarching framework for aligning or managing improvement programme including Lean management. On the other hand, Ferdowsian (2016) pointed out that existing Business Excellence/National Quality Awards/Total Quality Management approaches start with leadership and end with BE results. Rao (2016) also suggested there is a need to explore the soft part of leadership in achieving organizational excellence which still lacking. In the interest of bringing this literature gap, the present study aims to examine the BEMs research from 2009 to Aug 2020 in an effort to include Lean and leadership as the keywords used for article search.

\section{EVOLUTION OF BE AND LEADERSHIP THEORY}

\subsection{Business Excellence Model (BEM)}

The topic of excellence starts up with Peters and Waterman (1982) published well-known book In Search of Excellence - Lessons from America's Best-Run Companies. There are many proposals for the success criteria behind excellence and a definition of excellence. Peters and Waterman (1982) have one major contribution on their early acknowledgement of the importance of the soft dimension as success criteria for excellence such as shared values, staff, skills, style and systems together with the hardware of strategy and structure. Besides, recognizing many intangible organizational phenomena like norms, beliefs, values, styles and patterns of behaviors by concentrating on the soft dimensions. Research on excellence (Hermel \& Remis-Pujol, 2003; Dahlgaard \& Dahlgaard-Park, 2005) pointed out that Peter and Waterman's (1982) soft criteria, which included organizational culture, should be given a higher weight. Thus, the soft factors such as leadership, people and the human factor are the main criteria from the BEMs. 
In Canada, the CAE Quality Award was first developed in the year 1984. Since then, more than 300 public and private sector organizations have been recognized with this award (National Quality Institute, 2007). In the USA, it was followed by the Malcolm Baldrige National Quality Award (MBNQA) introduction in the year 1987. MBNQA gradually gained recognition as a de facto global standard on customer-oriented management practices and systems when it assisted US industry in revitalizing its competitiveness. In 1987, the Australian Business Excellence Framework was also introduced known as the fourth globally quality award.

With the support of the European Commission and European Organization for Quality Management, the European Quality Award was established in 1991 (it was called as European Excellence Award since 2004) based on the EFQM model. Objectively, it was to boost the position of Western European firms in the global market by accelerating the quality acceptance as an approach for a worldwide competitive advantage. Several countries in Asia have evolved their own BEMs as well concurrently with Europe including India in 1994, Singapore and Japan in 1995, the Philippines in 1997, Fiji in 1998, Thailand in 2001. The majority are adopting or using the MBNQA and EFQM as their reference. In India, the CII-EXIM Bank Award is based on the EFQM model and followed by the Singapore Quality Award which is derived from the MBNQA, EFQM and Australian Excellence Award. Conversely, the "Prime Minister Quality Award" of Malaysia has its self-determining criteria (Talwar, 2011).

In the evolution of BE, various opinions exit with its relationship with TQM. Some authors like Dahlgaard-Park (2011) also proposed that BE replaced TQM. Adebanjo (2001) argued that the term TQM was substituted with BE in the mid-1990s and above-mentioned quality models were renamed as Business Excellence Models (BEMs). The main reason for the requirement to differentiate BE from "old TQM" was due to the large number of different interpretations and methods of implementation that had become an ambiguous term (Mann, 2008). It is also believed that a high number of reported TQM failures is contributed by this lack of clarity and understanding of TQM (Evans \& Lindsay, 2005; Black \& Revere, 2006; Tickle, Mann, \& Adebanjo, 2014).

BE can be defined as "excellence in strategies, business practices, and stakeholder related performance results that have been validated by assessments using proven business excellence models (BEMs)" (Adebanjo \& Mann, 2008). Initially, BEMs aimed to deliver support for companies in their business success and search for excellence (Enquist, Johnson \& Ronnback, 2015). The procedure of working with business BEMs are referred to as "self-assessment", which reflects the step "to help organisations identify their current strength and pin-point the areas where they need to improve their performance" (EFQM, 2013).

BEMs have provided the milestone for excellence that facilitated numerous of organizations throughout the world to access their excellence level to identify areas for improvement and to take adequate actions for producing improvements. However, BEMs do have some limitations and are not the panacea for all challenges. For instance, award-winning organizations have achieved excellent financial results while their financial performance has not always been the best in their industry (Talwar, 2011). Conversely, some excellence companies unwilling to apply award maybe cause of required additional effort, time-consuming and awards process can encompass distraction (Tickle et al., 2014). In reality, a recipient of this BE Award desires to distinguish the recipients against other companies for implementing best practices and recording significant productivity achievements. The award winners achieved stronger financial performance, drive innovation, be 
customer-centric, raise productivity and reduce operational costs. The adoption of best practices of BE would indirectly improve the firm's global competitiveness.

\subsection{Leadership Theories}

The standing of leadership has been stressed frequently in the quality management area (Laureani \& Antony, 2017). Regardless of such thought, little study has been espoused concerning the traits or styles in which leadership is deployed to achieve BE. This study provides attention to this research gap with the hope of simulating more systematic research efforts. Thus, the mutual influence of leadership traits or styles on the placement of Lean and BE would be emphasized in the current study.

The definition of 'leadership' enriches in the literature. Yukl (2006) defined that leadership is a process where leaders motivate followers in achieving the objective and shared task. Pfeffer and Salancik (1975) stated that the leader exhibit relational-oriented and task-oriented behaviour. Ohio state leadership studies also defined two types of leadership behaviour included initiating structure and consideration. Initiating structure leader is related to the task accomplishment whereas in consideration refers to the leader act in a supportive and friendly manner. Even through the Michigan studies supported both relations-oriented behaviour and task-oriented behaviour, but the study also gives rise to participative leadership as the third category. In relations leadership style is that managers are more helpful, supportive and towards followers. They show confidence, trust, approachable understand the problem of their subordinate's problems. In contrast, task-oriented leadership roles are scheduling, planning, organizing activities and task to followers and also managers who provide technical assistance to their subordinates (Yukl, 2006). It is an assumption that all managers are a leader (Hunter, Bedell-Avers \& Mumford, 2007; Fayyaz, Naheed, \& Hasan, 2014). Hunter et al., (2007) further explained that leader behaviours influence followers' perceptions and actions resulting in some type of desired outcomes ultimately. In contrast, followers expected leadership which impact each of them consistently.

These two extreme behaviours leader is rarely either completely people-oriented or completely task-oriented in practice. However, it is clearly generalisations useful only in theory (Laureani \& Antony, 2017). This dichotomy also undertakes that high levels of both extremes are best in all situations. Kerr, Schriesheim, Murphy and Stogdil (1974) argued that the best leaders' behaviour might be contingent on the situation in reality, as mentioned by the contingency theorists of leadership. Moreover, different situations demand different kinds of leadership even with the same employee. This situational leadership approach has become one of the commonly used style globally because leaders need to adapt to the rapid changing of the business environment and so decisions making. This style also benefits to improve employee commitment and upsurge employee retention. In fact, the majority of the leaders only apply one leadership style regardless of the situation.

Most of the literature on leadership concerning Lean and BE included transformational perspective which saying that leaders develop and enhance a vision (Yukl, 2006). Burns (1978) described that transformational leaders as the change agents that developing, communicating and demonstrating a vision for the organisation or team, which inspiring subordinates to that vision. Lean management challenges leadership to change themselves to the new ways of working, because in a Lean 
organization changes occur in all processes at all the areas of the organization, Therefore, a leader is expected to be a change agent for Lean implementation across the company. The transformational leadership style is that followers can recognize the leader's vision and values which focuses leading by example. A transformational approach emphasises on individual strengths and weaknesses of employees, enhancing their commitment and capabilities to meet organizational goals. While providing opportunities for professional and personal growth for each employee and this often made by seeking their buy-in for decisions (Loh, Yusof \& Lau, 2018). Contrary to this is transactional leadership which assisting companies to meet their present goal in an extra proficient way (Goodwin, Wofford, \& Whittington, 2001).

Dinh et al., (2014) have carried out an extensive qualitative review of leadership theory in the new millennium that has emerged since 2000 to 2012 from the ten top-tier journals included Leadership Quarterly. They have acknowledged a sum of 66 diverse leadership theory domains and a broad range of methodological approaches. They also suggested that future research required to establish integrative perspectives that review how different leadership theories that relate or operate simultaneously to affect the emergence of leadership phenomena. To conclude, leadership theory emphasizes many outcomes. For example, from the way leaders are perceived to leaders' influence on team performance, which also involves the actions of followers or team members.

\section{METHODOLOGY}

\subsection{Selection of Articles}

The authors chosen to focus the scope of systematic review on the BE methodologies for leadership and Lean effects in the review planning. The authors adopted systematic review procedure outlined by Magnani, Carbone and Moatti (2019) that aimed to increase reproducibility and deliver an appropriate means for synthesising a growing field of knowledge such as Lean, leadership and BE. Furthermore, this research methodology possible to diminish prejudice and to increase research transparency. The authors tracked the detailed description of steps. as showed in Figure 1 to select and analyse the literature. The first stage of systematic literature review, the authors use major databases such as Scopus, Web of Science, ScienceDirect, Emerald, and EBSCOhost to search peer-reviewed journal articles. The keywords in the field of 'title' and/or 'abstract' in English were searched as below:

- $\quad$ Business excellence and/or Leadership

- Business excellence and/or Lean

These three keywords are used to correspond to the main fields that reflect our scope of studies in which the authors have to examine a relationship. The study has chosen the recent 11 years articles that are from 2009 to Aug 2020. The initial search return from scientific and leading databases (i.e. Scopus, Web of Science, ScienceDirect, Emerald, and EBSCOhost) was 470 articles. The authors then further search in main journals which included Business Excellence \& TQM Journal, Total Quality Management Journal. The purpose is to supplement the initial search to detect articles that might have been overlooked. This sum up a total eligible article was 506. Any journals concentrating on an area other than quality and management, dissertations, books and duplicates 
would be excluded. Therefore, a total of 129 papers was obtained with these exclusion and inclusion criteria.

Figure 1: Search process and results

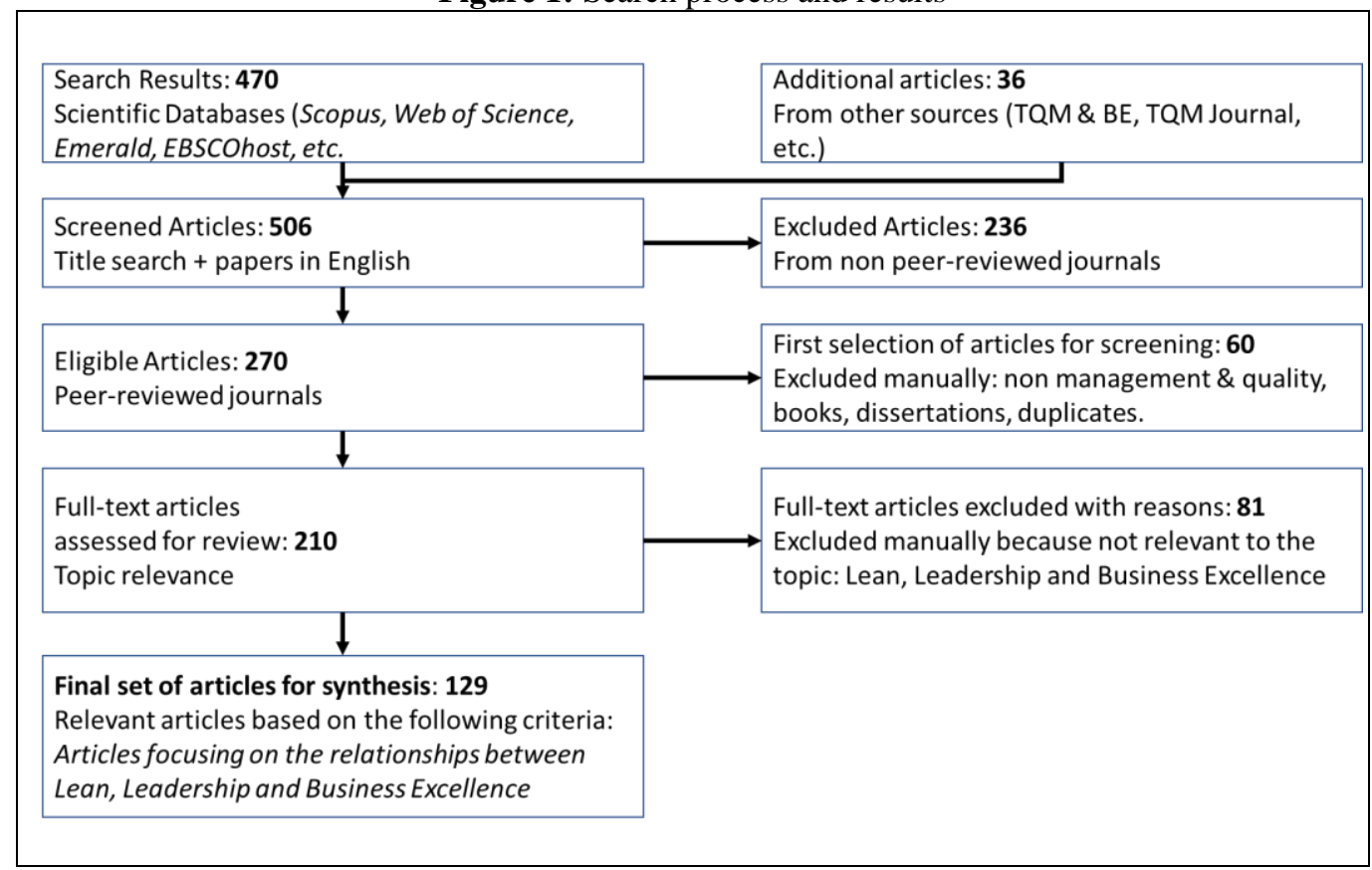

Source: Magnani, Carbone, \& Moatti (2019)

\section{REVIEW RESULTS}

The total numbers of articles with the initial search of 470 have been reduced further after excluding all the redundancies. Therefore, the entire number of reviewed articles linked to BE, leadership and Lean came down to 129 papers. This consists of 28 conceptual papers, 63 empirical studies, 18 works of literatures review, 5 exploratory studies and 15 case studies.

\subsection{Publication Distribution}

\subsubsection{Year of Distribution}

The circulation of papers presented in Figure 2 presents that academic interest in the subject has increased over time from 2009 to 2020. It has reached the most output in the recent three years from 2016 to 2019. However, the dip in articles in 2020 as a result of the journal search was only up to mid-August 2020. 
Figure 2: Publication of articles (2009-Aug 2020)

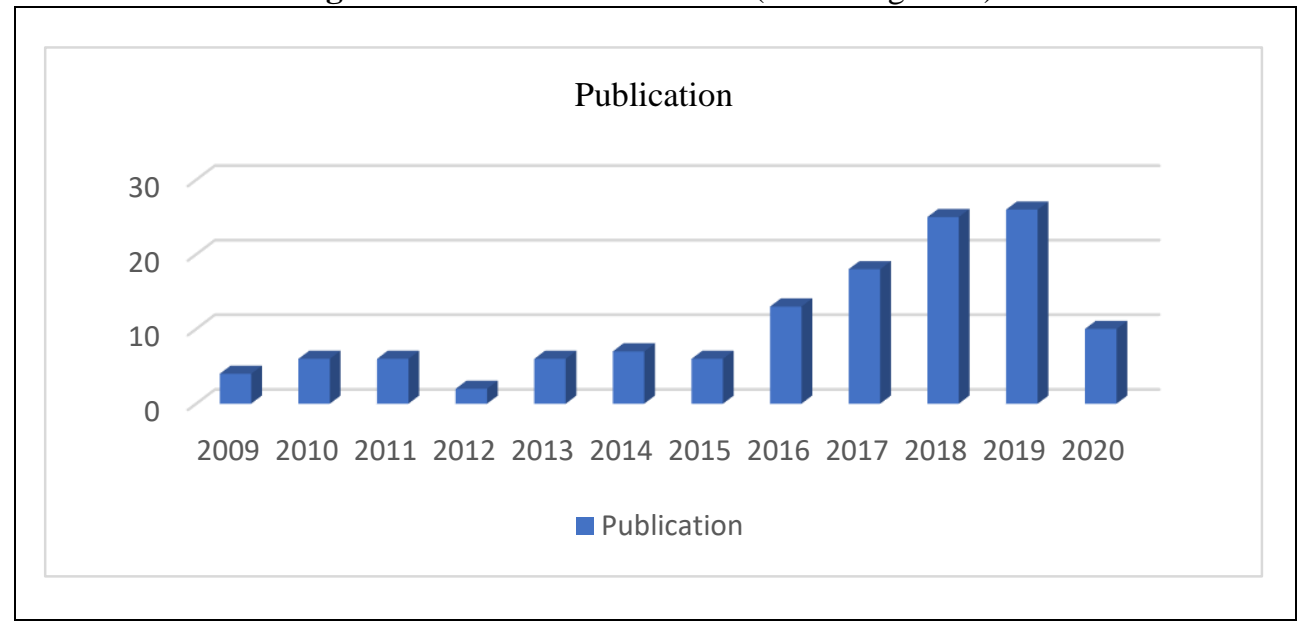

\subsubsection{Journals}

A total of 129 papers were used for this study and a full list is presented in the Appendix. Only journals with two or more articles are listed in Table 1 with a total 72 papers. The three leading journals are Total Quality Management and Business Excellence, International Journal of Lean Six Sigma and TQM Journal with contributed 28, 7 and 6 papers respectively. The authors also found articles were in journals dissemination to a variety of fields including manufacturing, family business, higher education, retail and distribution, healthcare, tourism management, airport, logistics services, and science and engineering. This signaling the dedication of the topic in disciplines and contexts are different from the original quality or manufacturing setting.

Table 1: Journals with two or more articles in the current literature review

\begin{tabular}{clc}
\hline \hline No & \multicolumn{1}{c}{ Journals } & Total \\
\hline 1 & Total Quality Management and Business Excellence & 28 \\
2 & International Journal of Lean Six Sigma & 7 \\
3 & TQM Journal & 6 \\
4 & International Journal of Quality and Reliability Management & 5 \\
5 & International Journal of Health Care Quality Assurance & 3 \\
6 & Journal of Manufacturing Technology Management & 3 \\
7 & International Journal of Production Research & 3 \\
8 & MATEC Web of Conferences & 2 \\
9 & Measuring Business Excellence & 2 \\
10 & Benchmarking: An International Journal & 2 \\
11 & Production Planning \& Control & 3 \\
12 & Total Quality Management & 2 \\
13 & International Journal of Productivity and Performance Management & 3 \\
14 & International Journal of Scientific and Technology Research & 2 \\
15 & International Journal of Supply Chain Management & 2 \\
\hline & $\quad$ Total & 73 \\
\hline
\end{tabular}




\subsection{Research Context}

Each published paper is to determine either there was a domineering country or industrial sector with the basis of research. Most of the empirical research papers were associated with a specific industry sector compared with conceptual papers which are not. In overall, the empirical studies are more than two times higher compared with conceptual paper then follow by literature review and exploratory studies. It was noticeable that the extended fields of application of Lean practices and $\mathrm{BE}$ in numerous industrial areas and services in recent years. For example, Lean practices and $\mathrm{BE}$ have grown in publications in other industries which include healthcare, education, public organization, and services compared with the more traditional manufacturing sector in the past.

Majority studies are based on qualitative and quantitative methodologies. In viewing the countries where research take place (Figure 3), it depicted that one article contributed by one country or named Others $(15.5 \%)$ was higher in comparison to countries that contributed more than one article. The top five countries with most papers were Malaysia with 18 articles (14.0\%), then followed by India with 16 articles (12.4\%), UK with 13 articles (10.1\%), US with 7 articles (5.4\%) and Brazil with 6 articles $(4.7 \%)$.

Figure 3: Countries where research take place

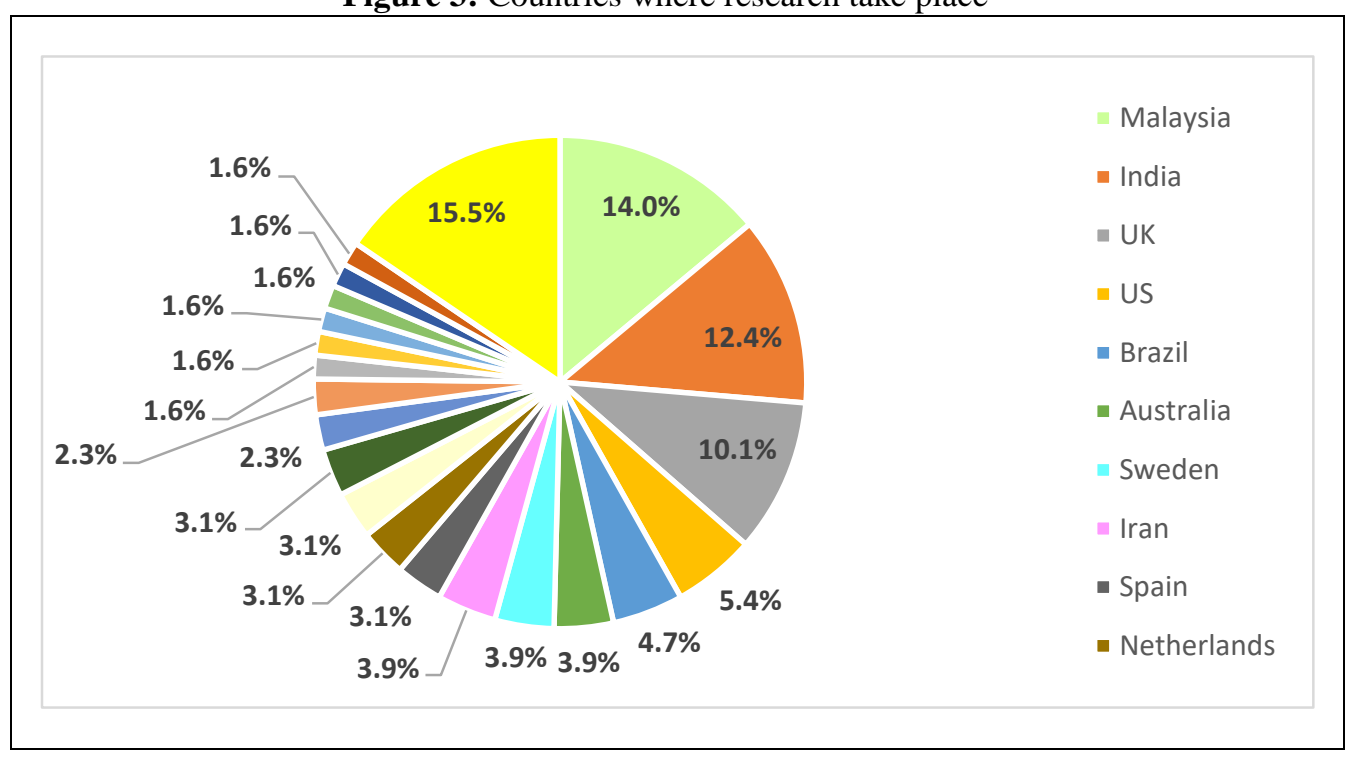

Through the total 129 papers the authors reviewed, the vast majority is empirical papers with approximately $48.8 \%$ (63 articles) shown in Table 2 . Then followed by conceptual papers contributed about $28.0 \%$ ( 28 articles) and literature review approximately $14.0 \%$ (18 articles). The remaining were case study and exploratory papers with $11.6 \%$ (15 articles) and $3.9 \%$ (5 articles) respectively. If compared with the selected literature review papers, the current study has included the latest papers from the Year 2020. This study has covered 3 variables (BE, Lean \& leadership) 
altogether whereby the majority of earlier literature papers are the combination of Lean and Leadership or Leadership and BE.

Table 2: Types of research paper

\begin{tabular}{clcc}
\hline \hline No. & Research paper & Total & Percent \\
\hline 1 & Conceptual paper & 28 & $21.7 \%$ \\
2 & Empirical studies & 63 & $48.8 \%$ \\
3 & Literature review & 18 & $14.0 \%$ \\
4 & Exploratory studies & 5 & $3.9 \%$ \\
5 & Case studies & 15 & $11.6 \%$ \\
\hline & Total & 129 & $100.0 \%$ \\
\hline \hline
\end{tabular}

\section{DISCUSSION}

\subsection{Overview of the Relationship between BE, Leadership and Lean}

BEMs has been extremely used in many countries. Mohammad et al., (2011) stated there were 83 countries with 94 applied National Quality/BE Awards overall. On the other hand, Talwar (2011) cited 100 BEMs or National Quality Awards being deployed in 82 countries worldwide.

Ferdowsian (2016) highlighted that existing Business Excellence/National Quality Awards/Total Quality Management approaches start with leadership and end with results. The leadership drives activities towards excellence in customer satisfaction and business results and that is the principle behind its award criteria (Talwar, 2011). Therefore, it is important to place the right effort and time of leader at the proper activities and acts to achieve a better result (Loh et al., 2018).

A recent study carried out shows that the adoption of Lean manufacturing has a significant effect on operational performance (Ghobakhloo \& Azar, 2018; Sahoo \& Yadav, 2018; Wickramasinghe $\&$ Wickramasinghe, 2017). Furthermore, many scholars have recognized Lean improvement initiatives as important to deploy BE (Slack, Brandon-Jones \& Johnston, 2013; Dale, 2003; Tickle et al., 2014).

Putting leadership, BE elements and Lean extracted from the literature, the authors propose the framework presented in Figure 4 to illustrate the relations between leadership, BE elements and Lean. In other words, Figure 4 is synthesized from selected articles in this study. A variable that appeared 5 times or more represented important variables or element in recent years study was quoted in Figure 4. 
Figure 4: A model of Lean and BE criterion (synthesized from selected articles)

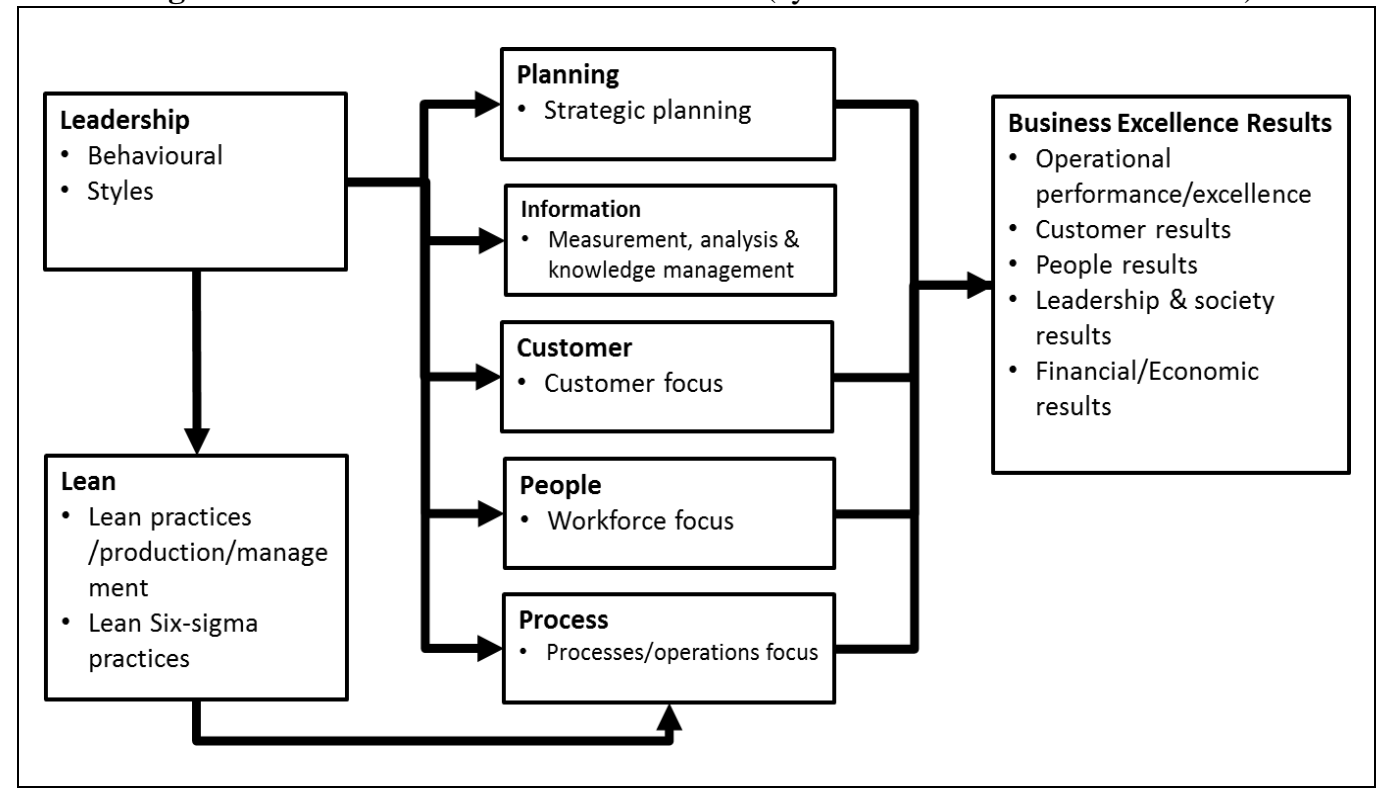

This model illustrated the key relationship identified in the literature.

1. The impact of leadership behaviour/styles on Lean initiatives within the organisation.

2. The impact of leadership behaviour/styles on BE elements (planning, MAKM, customer, people and process) within the organisation.

3. How (1) above has an impact on the processes/operations improvement in organization.

4. All the above combine to generate the BE results.

\section{KEY EMERGING THEMES / SUGGESTION FOR FUTURE RESEARCH}

The reviews showed that effective leaders have distinctive behaviors/styles such as empowering leadership style that is positively connected to the application of Lean practices (van Assen, 2018b). Yukl (2006) has organized leadership behaviors/styles into contingency perspective, competency perspective, transformational perspective, behavioral perspective and implicit leadership perspective. Nevertheless, the large areas of overlap among themselves which not yet been defined accurately with more traditional styles previously studied in the literature. Besides, Dinh et al., (2014) addressed to develop an integrative perspective of leadership in future research with regard to disparate leadership theories.

Laureani and Anthony (2019) corresponded on a mutual definition of leadership as 'motivating, influencing and enabling others to contribute toward the success and effectiveness of the organizations that they are members. Leadership is one of the key factors of numerous critical success factors for Lean implementation as evidence shows in empirical research (Jadhav, Mantha, \& Rane, 2014; Albliwi, Anthony, Lim \& van der Wiele, 2014). Moreover, the success of a Lean 
implementation is determined by leadership styles (Mann, 2008; Spear \& Bowen, 1999; Van Assen, 2018a). However, changing leadership style is not that easy, it possibly takes more efforts and a long time (Loh et al., 2018). Furthermore, Anderson and Sun (2015) raised a call to leadership researchers to generate a new leadership model collectively which encompasses the exclusiveness about these various suggested new styles. Describing the leadership traits are more encouraging to a successful Lean deployment, therefore, organizations can ensure the right leaders are in place if they embark on such a journey.

This systematic literature review also emphasized that there is a need to extend research on leadership in BE Models. Laureani and Anthony (2019) proposed the design of future research to differentiate leadership style between Middle management and Executive/Senior management in organisations. This effort may extend to different industry sectors included manufacturing and services. It is may be a different level of position, industry sectors and across organisations of unlike size than possible required of a dissimilar style of leadership. Thus, there is essential to evolve the latest leadership model that comprehend the leadership traits required for Lean implementation.

Zdrilic and Dulcic (2016) argued that BEM is more holistic in nature than earlier TQM models and core values. Specifically, BE ensures full integration of improvement activities in an organisation. Leadership is a key importance to any approach in achieving excellence. According to the EFQM Excellence Model (2015), an organization need clear strategic direction and strong leadership to accomplish sustained success, which is called Enablers. Therefore, it would be interesting for future research to test some of the leadership styles or traits empirically. This would provide further insight into driving forces to the BEMs.

\section{CONCLUSION}

Lean has become the most prevalent business strategy for positioning continuous improvement in public service organizations, manufacturing and service (Albliwi et al., 2014). Continuous improvement is the foremost goal for any organization to assist them to attain operational excellence and quality enhancement, and also to improve performance (Laureani \& Anthony, 2017). Recent studies seemed to have Lean implementation increasing in service context from traditional manufacturing context. This includes Lean applied in for airport services (Syltevik, Karamperidis, Antony, \& Taheri, 2018). Nevertheless, some companies are struggling to turn Lean into success by quoting a lack of leadership despite its success in some industry. Snee (2010) described how Lean is an effective leadership development tool whereby leaders allow an organization to transform from one paradigm and way of working to another.

Leadership appears as driver or enabler role in most of the BE models. This included prominent BEMs such as Deming Prize, MBNQA, EFQM and Kanji's Business Excellence Model (KBEM). However, numerous new leadership styles have been introduced in the past decade (Anderson \& Sun, 2015), but they have not yet been appropriately defined (Laureani \& Antony, 2017). This offers an attention to such challenges with the expectation of simulating more systematic research efforts on the mutual influence of leadership and Lean based construct on the BE dimensions. 
The emphasis of this study is to consolidate the existing knowledge on leadership, Lean and BE to provide a space for practitioners and researchers in quest of implementing Lean and BEM in an organization and offering recommendations for future studies. It is very clear that leadership is a crucial factor for Lean success and its impact would be the subject of future study to decide which leadership behaviors/styles are more favorable to success. On the other hand, there is required to create an up-to-date leadership model that encompasses the leadership styles/trait desirable for BE and Lean. For example, current review work maybe expanded by a focus on general leadership to more specific leadership style such as transformational style that is linking with Lean and BE. This foresees managerial implications that may help the organization to ensure the right leadership in place to embark on BE. The future direction may include new era of initiative program like Fourth Industrial Revolution (IR 4.0) on top of Lean to engage on a new development of literature knowledge.

This systematic literature review also produces an important methodological contribution by applying elements of systematic reviews originating from the termed BE to the leadership behaviour and Lean practices of field studies. There are limited systematic concepts and research are often unwell operationalised to assist the organization in their efforts to deploy BE. With this, they can identify which leadership style or trait to drive BE and which Lean tools is effective to deploy in process continuous improvement and achieve superb results.

\section{ACKNOWLEDGEMENT}

The authors would like to thanks the managerial executives of Malaysia E\&E's manufacturing industries for participating in the survey.

\section{REFERENCES}

Adebanjo, D. (2001). TQM and business excellence: is there really a conflict? Measuring Business Excellence, 5(3), 37-40.

Adebanjo, D. \& Mann, R. (2008). Business Excellence. BPIR Management Brief. Palmerston North, New Zealand: BPIR.

Albliwi, S., Antony, J., Lim, S. A. H., \& van der Wiele, T. (2014). Critical failure factors of Lean Six Sigma: a systematic literature review. International Journal of Quality \& Reliability Management, 31(9), 1012-1030.

Anderson, M. H., \& Sun, P. Y. T. (2015). Reviewing leadership styles: Overlaps and the need for a new 'full-range' theory. International Journal of Management Reviews, 19(1), 76-96. doi: $10.1111 /$ ijmr.12082

Black, K. \& Revere, L. (2006). Six Sigma arises from the ashes of TQM with a twist. International Journal of Health Care Quality Assurance, 19, 259-266.

Burns, J. M. (1978). Leadership. New York: Harper and Row.

BPIR (2019). Business Performance Improvement Resource. Retrieved from https://www.bpir.com/business-excellence-bpir.com.html

Dahlgaard, J. J., \& Dahlgaard-Park, S. M. (2005, September 13-16). In search of excellence-past, present and future. Paper presented at the International Conference on Quality (ICQ'05), Tokyo, Japan. 
Dahlgaard-Park, S. M. (2011): The quality movement: Where are you going? Total Quality Management \& Business Excellence, 22(5), 493-516.

Dale, B. (2003). Managing Quality. Oxford: Blackwell Publishers.

Dinh, J. E., Lord, R. G., Gardner, W. L., Meuser, J. D., Liden, R. C., \& Hu, J. (2014). Leadership theory and research in the new millennium: Current theoretical trends and changing perspectives. The Leadership Quarterly, 25(1), 36-62.

Enquist, B., Johnson, M. \& Ronnback, A. (2015). The paradigm shift to Business Excellence 2.0., International Journal of Quality and Service Sciences, 7(2/30), 321-333.

European Foundation for Quality Management (EFQM). (2013). The Excellence Model. EFQM, Brussels.

Evans, J. R. \& Lindsay, W. M. (2005). An Introduction to Six Sigma \& Process Improvement. Cincinnati, OH: Thomson South-western Publishing Company.

Fayyaz, H., Naheed, R., \& Hasan, A. (2014). Effect of Task Oriented and Relational Leadership Style on Employee Performance; Moderating Impact of Communicator Competence. Journal of Marketing and Consumer Research, 3(2014), 1-9.

Ferdowsian, M. C. (2016). Total business excellence - a new management model for operationalizing excellence. International Journal of Quality \& Reliability Management, 33(7), 942-984.

Ghobakhloo, M. \& Azar, A. (2018). Business excellence via advanced manufacturing technology and lean-agile manufacturing. Journal of Manufacturing Technology Management, 29(1), 2-24.

Goodwin, V. L., Wofford, J. C., \& Whittington, J. L. (2001). A theoretical and empirical extension of the transformational leadership construct. Journal of Organizational Behavior, 22(7), 759-774. doi: 10.1002/job.111

Hermel, P., \& Pujol, F. R. (2003). An evolution of excellence some main trends. The TQM Magazine, 15(4), 230-243.

Hunter, S. T., Bedell-Aver, K. E., \& Mumford, M. D. (2007). The Typical Leadership Study: Assumptions, implications, and potential remedies. The Leadership Quarterly, 18, 435446.

Jadhav, J. R., Mantha, S. S. \& Rane, S. B. (2014). Exploring barriers in lean Implementation. International Journal of Lean Six Sigma, 5(2), 122-148.

Kanji, G. K. (2002). Measuring Business Excellence. London/New York: Routledge.

Kerr, S., Schriesheim, C. A., Murphy, C. J., \& Stogdill, R. M. (1974). Toward a contingency theory of leadership based upon the consideration and initiating structure literature. Organizational Behaviour and Human Performance, 12, 62-82.

Laureani, A., \& Antony, J. (2017). Leadership characteristics for Lean Six Sigma. Total Quality Management \& Business Excellence, 28(3-4), 405-426.

Laureani, A. \& Antony, J. (2019) Leadership and Lean Six Sigma: a systematic literature review. Total Quality Management \& Business Excellence, 30(1-2), 53-81.

Loh, K. L., Yusof, S. M. \& Lau, D. H. C. (2018). Blue ocean leadership in lean Sustainability. International Journal of Lean Six Sigma. doi: 10.1108/IJLSS-06-2016-0029

Magnani, F., Carbone, V. and Moatti, V. (2019). The human dimension of lean: a literature review. Supply Chain Forum: Supply Chain Forum: An International Journal. doi: $10.1080 / 16258312.2019 .1570653$

Mann, R. (2008). Revisiting a TQM research project: the quality improvement activities of TQM. Total Quality Management \& Business Excellence, 9(7-8), 751-761. 
Mohammad, M., Mann, R., Grigg, N., \& Wagner, J. P. (2011). Business Excellence Model: An overarching framework for managing and aligning multiple organisational improvement initiatives. Total Quality Management \& Business Excellence, 22(11), 1213-1236.

National Quality Institute (2007). Canada Awards for Excellence. Retrieved from https://excellence.ca/en/knowledge-centre/articles/why-nqi-for-organizations-inbritish

Peters, T. J. \& Waterman, R. H. (1982). In Search of Excellence: Lessons from America's Best Run Companies $\left(1^{\text {st }}\right.$ Ed). New York: Harper \& Row.

Pfeffer, J., \& Salancik, G. R. (1975). Determinants of supervisory behavior: A role set analysis. Human Relations, 38, 138-153.

Rao, M. (2016), Debunking myths about soft leadership and exploring it to achieve organizational excellence and effectiveness. Industrial and Commercial Training, 48(7), 362-366.

Sahoo, S. \& Yadav, S. (2018). Lean implementation in small- and medium-sized enterprises: An empirical study of Indian manufacturing firms. Benchmarking: An International Journal, 25(4), 1121-1147. doi: 10.1108/BIJ-02-2017-0033

Slack, N., Brandon-Jones, A. \& Johnston, R. (2013). Operations Management. Essex, UK: Prentice Hall.

Snee, R. D. (2010) Lean Six Sigma-Getting Better All the Time. International Journal of Lean Six Sigma, 1, 9-29. doi: 10.1108/20401461011033130

Spear, S. \& Bowen, H. K. (1999). Decoding the DNA of Toyota production system. Harvard Business Review, 77(5), 97-106.

Syltevik, S., Karamperidis, S., Antony, J., \& Taheri, B. (2018). Lean for airport services: a systematic literature review and agenda for future research. International Journal of Quality \& Reliability Management, 35(1), 34-49.

Talwar, B. (2011). "Business excellence models and the path ahead ..." The TQM Journal, 23(1), 21-35.

Tickle, M., Mann, R., \& Adebanjo, D. (2014). Deploying business excellence - success factors for high performance. International Journal of Quality \& Reliability Management, 33(2), 197-230.

Van Assen, M. F. (2018a) Exploring the impact of higher management's leadership styles on Lean management. Total Quality Management \& Business Excellence, 29,11-12, 1312-1341. doi: 10.1080/14783363.2016.1254543

Van Assen, M. F. (2018b). Lean, process improvement and customer focused performance. The moderating effect of perceived organisational context. Total Quality Management \& Business Excellence, 32(1-2), 57-75. doi: 10.1080/14783363.2018.1530591

Wickramasinghe, G. L. D., \& Wickramasinghe, V. (2017). Implementation of lean production practices and manufacturing performance: The role of lean duration. Journal of Manufacturing Technology Management, 28(4), 531-550. doi: 10.1108/JMTM-08-20160112

Yukl, G. A. (2006). Perspectives on Effective Leadership Behaviour. In Leadership in organizations (pp. 54-85). Upper Saddle River, NJ: Pearson Education.

Zdrilic, I. \& Dulcic, Z. (2016). Business Excellence as a Success Factor for the Performance of Large Croation Enterprises, Management, 21(1), 145-162. 